\title{
BORDER CROSSING AND SELF-PLACEMENT OF CHARACTERS WITH A MIGRATORY BACKGROUND IN CONTEMPORARY GERMAN NOVELS
}

\section{Annabelle Jänchen}

J. E. Purkyně University. Ústí nad Labem, Czech Republic. Email: annabelle.jaenchen[at]students.ujep.cz

\section{Abstract}

The existence of a "Migrant literature" is heavily debated in German studies, especially when it comes to authors like those of the third voice, who are socialized in Germany and speak German as their mother tongue. Nonetheless, novels that deal with migration and living with migrant backgrounds have similar characteristics. This article is primarily about the topic of crossing borders in such migrant novels by Olga Grjasnowa, Sasha Marianna Salzmann and Dimitrij Kapitelman. Which effects does border crossing have on characters with a migration background? The novels examined are not only characterized by a border crossing of migration from east to west, but actually even by multiple border crossings on different levels, that are always linked to each other. The literature of the third voice unites aspects of migration, but equally also aspects of adolescent literature and family sagas. That is shown, among other things, in the presentation and meaning of boundaries and their crossings as identitycreating moments and as coping strategies. Therefore, these border crosser stories enable new perspectives compared to conventional family sagas and adolescent literature.

\section{Keywords}

migrant literature; adolescent literature; family sagas; border crossing; transit space; self-transgression; intercultural characters; liminal experiences; alienation; third voice

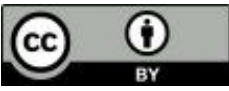

This work is licensed under a Creative Commons «Attribution» 4.0 International License 


\title{
ПЕРЕСЕЧЕНИЕ ГРАНИЦ И САМО- РАЗМЕЩЕНИЕ ПЕРСОНАЖЕЙ МИГРАЦИОННОГО ПРОИСХОЖДЕНИЯ В СОВРЕМЕННЫХ НЕМЕЦКИХ РОМАНАХ
}

\author{
Янхен Аннабель \\ Университет Яна Евангелиста Пуркине. Усти-над-Лабем, Чехия. \\ Email: annabelle.jaenchen[at]students.ujep.cz
}

\section{Аннотация}

Существование «литературы мигрантов» активно обсуждается в германистике, особенно когда речь заходит об авторах «третьего голоса», которые социализированы в Германии и говорят на немецком как на родном языке. Тем не менее, романы, посвященные миграции и жизни мигрантов, имеют схожие характеристики. Эта статья в первую очередь посвящена теме пересечения границ в романах о мигрантах Ольги Грязновой, Саши Марианны Зальцманн и Дмитрия Капительмана. Какие последствия имеет пересечение границ для персонажей с миграционным прошлым? Рассмотренные романы характеризуются не только пересечением границы в процессе миграции с востока на запад, но фактически даже множеством пересечений границ на разных уровнях, которые всегда связаны друг с другом. Литература третьего голоса объединяет аспекты миграции, а также аспекты подростковой литературы и семейных саг. Это проявляется, среди прочего, в представлении и значении границ и их пересечений как моментов создания идентичности и как стратегий выживания. Таким образом, эти истории о пересечении границ открывают новые перспективы по сравнению с обычными семейными сагами и литературой для подростков.

\section{Ключевые слова}

литература мигрантов; литература для подростков; семейные саги; пересечение границ; транзитное пространство; само-трансгрессия (саморазрыв); межкультурные персонажи; пороговые переживания; отчуждение; третий голос

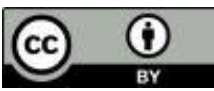

Это произведение доступно по лицензии Creative Commons «Attribution» («Атрибуция») 4.0 Всемирная 
Журнал Фронтирных Исследований. 2021. No 2 | ISSN: 2500-0225

Пограничные исследования в современной европейской литературе | Doi: https://doi.org/10.46539/jfs.v6i2.290

\section{INTRODUCTION}

The existence and role of a "Migrant literature" within German-language literature is currently the subject of intense debate in both the public (cf. Stanišić, 2008, Grjasnowa, 2017) and academic (cf. Hausbacher, 2009, Cornejo et al, 2014) fields. I took this discussion as an opportunity to examine the extent to which works by such writers described as "migrant authors" actually have similarities in terms of content and form in my study Die dritte Stimme (cf. Jänchen, 2019). In considering these bilingual, intercultural authors, Carmine Chiellino's concept of the "topography of voices", in which intercultural authors are divided into nine voices, has proven to be helpful (cf. 2001, p. 54). The first three voices in particular were relevant to my analysis. Migrated authors who continue to write in their native language in the arrival countries are representatives of the first voice. The second voice is understood to mean authors who switch to another language for their literary work in the course of their migration. The third voice is that of the authors who had still been children when they arrived in the new country and who speak the new language as their mother tongue in the social and school environment, while the original mother tongue only plays a role in the family environment.

While it is more common in sociology to speak of the generation concept (cf. Aumüller, 2010), in literary studies it is more appropriate to assume native speakers and language changers in the context of migration, as Chiellino does when he distinguishes intercultural voices. But why is the distinction between language changers and those who continue to write in their native language important at all? Oppenrieder and Thurmair show in their study that language makes a significant contribution to identity formation and group membership (2003, pp. 41-42). Switching to German can therefore help to break away from the literary traditions of the home country and rather to continue writing on German, European or intercultural literatures. Furthermore, this already shows that the authors of the third voice are those with whom categories such as "Migration literature" reach their limits. A comparison of the literatures of the second and third voice has shown that the latter addresses some of the characteristics of the literature of the second voice, which is classically understood as "Migration literature", but also develops its own new trends such as the perspective of children, the alienation of generations or the renewed crossing of boundaries in adulthood (cf. Jänchen, 2019, pp. 82-84). The latter is to be revealed in this article as one of the most important identity-creating moments in this literature of the "third voice". 


\section{REPRESENTATION AND MEANING OF BORDER CROSSING IN LITERATURE}

Crossing borders is viewed from many different scientific perspectives. Border studies relate in particular to social geography and social sciences, but borders are also a special subject in literary studies. For instance, in the Arctic University of Norway there is a specialized research group analysing border poetics and border culture (cf. Schimanski \& Wolfe, 2017). With regard to German literature, there are several works on literary border crossings and transit spaces. In the following, the most important aspects and characteristics of cross-border literature will be summarized based on this secondary literature.

Pabis uses the terms of the border and the crossing of borders as part of the phenomena of foreignness and says that without drawing and crossing borders, neither binary concepts such as own and foreign, nor experiences of the foreign would be imaginable at all (2017, p. 27). Waldenfels, too, emphasizes the importance of the foreign at borders when he assumes that the foreign appears at borders (of every order) in the form of the extraordinary $(2006$, p. 9). The encounter and mixing of cultures, languages and identities associated with crossing the border is what makes the border zone characteristic as a scene of self-crossing (Pabis, 2017, p. 30). This self-transgression can lead to alienation from the world and oneself (Waldenfels, 1990, p. 32), which is reflected in cross-border literature.

Pabis focuses on migration as a spatial and political crossing of borders as well as on personal transitional experiences and border zones of the migratory characters, who often undergo liminal experiences apart from national borders (such as adolescence, sexual maturity, illness or death) (2017, p. 47). Novels that deal with border crossings in the context of migration, travel or personal liminal experiences such as puberty are border crosser stories. According to Pabis, these novels, which deal especially with stories of migration as family stories (as a major part of the novels of the third voice does), differ from classic family sagas (as they are described by Assmann, 2007, p. 73) in that they are particularly driven by experiences of disruption, which can be found above all in border crossings (2017, p. 46). Thus, migrant family novels seem to add a perspective to the genre of family sagas. According to Pabis, it is the perspective of the tension between the former communist East and the today's German cultural memory (p. 47). As this article will show, this will not remain the only broadening or shifting of perspective that is revealed in connection with the crossing of boundaries.

Likewise, Hinojosa Picón examines the meaning of borders in stories about migrating families and concludes that borders play an important role in the memory of families and that they are a recurring motif (2019, p. 166). 


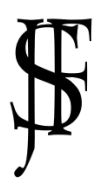

Журнал Фронтирных Исследований. 2021. No 2 | ISSN: 2500-0225

Пограничные исследования в современной европейской литературе | Doi: https://doi.org/10.46539/jfs.v6i2.290

The history of the migrant family is shaped by cultural exchange at borders that the ancestors have already experienced, and which is still inscribed in the texts in later generations (p. 169). This refers to the psychological term of transgenerational trauma (cf. Rauwald, 2013), which is also examined in the field of literary studies as in Drosihn et al 2020. Hinojosa Picón concludes that, consequently, the result of transgenerational trauma is a literature full of contrasts (2019, p. 169). The act of crossing a border enables the protagonists to reflect on their own origin and family history. By crossing borders themselves, the characters gain access to "Contact Zones" - "social spaces where cultures meet, clash, and grapple with each other" (Pratt, 1991, p. 34) - that have been entered, passed and left by their own family members or ancestors over the years (Hinojosa Picón, 2019, p. 172). In so doing they can experience - on the basis of their often multilingual family memories - the contradictions and attempted adaptations and assimilations as well as the divide and blending that their ancestors and other migratory characters went through before (p. 172).

Hardtke et al (2017) examine the special circumstances of fleeing, the representation of places of refuge and refugee characters that emerged in the course of the European refugee crisis around 2015. Here, borders and border crossings are rather conceived in the context of political discussions and asylum policy and are therefore a reflection of the big questions that the European Union has to face with regard to how it deals with refugees and how it sees itself. Borders become a defining criterion here, since a refugee is someone who has crossed a geopolitical border between his/her home country and a foreign country (p. 13) In the context of flight, the border often stands for insurmountability on the one hand and illegal transgression on the other, as Steidl (2017) makes clear in her contribution, in which she highlights the refugee as a border violator character. However, this political level only plays a marginal role in the novels of the third voice.

Finally, most secondary texts agree that there is some kind of a third, hybrid space (based on what Bhabha refers to as hybridity (cf. 1994)) that is, according to Pekar, used as a processing or coping strategy (2017, p. 134). As an example, Pekar names the creation of a new language space in Feridun Zaimoglu's Kanak Sprak (1995) and the waiting room as a transit space in Lion Feuchtwanger's Exil (1940) (pp. 139-140). According to Wilhelmer, something significant happens at such transit spaces, such as expansion of consciousness and fascination, but also overstimulation, irritation and selfreflection (2015, pp. 10-11). Train stations and airports are places of transit par excellence, customs and passport control are recurring motifs. Hausbacher states that the representation of border areas marks a situation of crisis or change (2009, p. 139). Hence, transit between places and especially between 
nations is frequently accompanied by a transit on the personal level of the character. In the following, these characteristics of cross-border literature as the situations of transit, the transgenerational memories that can be experienced in contact zones, the broadening and shifting of perspectives, the selftransgression and the meanings of foreignness will be examined using the example of three contemporary German novels.

\section{BOUNDARIES BETWEEN LIFE AND DEATH IN OLGA GRJASNOWA'S DER RUSSE IST EINER, DER BIRKEN LIEBT}

Olga Grjasnowa's debut novel, published in 2012, is about the RussianJewish protagonist Mascha, who was born in Baku in the 1980s and who fled to Germany with her family in the 1990s. One of the story lines is about the pogroms in Baku in January 1990, the civil war-like conditions in the conflict between Azerbaijani and Armenians and the relocation of Mascha's family to Germany. The other story line shows the present time in Germany, in which Mascha's friend Elias suddenly dies, and so she falls into grief and depression and decides to take a job in Israel in order to gain distance from her situation, but also from her family and Germany. However, in Israel, too, she finds no consolation in her Jewish roots. She does not know a home and thus a clear geographical reference point. She cannot clearly define herself as Russian, Azerbaijani, German or Jewish. Besides, she speaks Russian and German as mother tongues and five more languages due to her job as translator. The character breaks through any criteria of homogeneity in terms of territory, religion, ethnicity and language.

When Mascha clears out the shared apartment after Elias' death, she suddenly remembers the first time when she had to leave her usual life in a hurry. At that time, in Baku, she was allowed to choose which things she wanted to take with her to Germany, although, as she later discovered, she could no longer use those things she had brought with her in the German asylum seekers' home since priorities have changed a lot as a consequence of the border crossing (Grjasnowa, 2012, p. 148). This first crossing of boundaries triggers the character's inner turmoil and homelessness. She has never overcome the effects and her childhood suddenly came to an end (p. 47). In the family's transgenerational memory, the country to which they were supposed to flee is actually remembered as the land of horror, where they never wanted to go to:

In the first instance, my parents found the idea of going to Germany of all places absurd. In 1994 my mother said she would never set foot in this country since the ashes were still warm there. My grandmother was a survivor. Nine months later, my parents applied for entry at the German embassy. In 1995 our application was approved and we started selling our things: first the electrical appliances and 
kitchen equipment, then the furniture. [...] In 1996 we were in Germany. In 1997 I was thinking about suicide for the first time. (p. 51, translation by AJ) ${ }^{1}$

Not only having to leave her home, but also having to flee - of all places - to the country of the Nazi perpetrators and growing up there from now on not only as a Russian-Jewish Azerbaijani, but also as a German, tears the character apart in a manner in which death seems to be the only way out. In Elias, however, she later found something like a home for the first time in Germany. With his death, her world is consequently turned upside down for a second time. The only way out seems to be another border crossing, another escape from a place where she has repeatedly lost a feeling of home. This border crossing will also result in death: on arrival at Ben Gurion Airport in Tel Aviv, Mascha's laptop is shot (p. 161) by border officials. The following can be heard over the loudspeakers: "Do not be alarmed by gunshots because the Israeli security needs to blow up suspicious passenger luggage" (p. 164). The stickers with Arabic characters on the keyboard of her laptop suggested a terrorist attack. In addition, Mascha is interrogated extensively, the work visa is checked, and her luggage is searched by soldiers.

In Israel she meets Tal, with whom she develops an intense friendship. Tal later persuades her to travel to Palestine: "If you still feel something for me, then come with me" (p. 254, translation by AJ) ${ }^{2}$. So, there is a third border crossing, which Mascha no longer takes seriously:

"What happens when you discover in Ramallah that you don't have your passport with you. Will you then not be allowed to go back to Israel?"

"This is not a Sunday trip", said Tal.

"It looks pretty much like Sunday to me here." (p. 259, translation by AJ) ${ }^{3}$

Returning has never been an option for Mascha. Her friends and family in Germany had to hope in vain that she would ever return from Israel. Likewise, she does not seem to have any plans to return from Palestine, since she doesn't even take her passport with her. None of these border crossings were ever truly voluntary and there was never a turning back. Only at the very end

1 Original quote: "Die Vorstellung, ausgerechnet nach Deutschland zu gehen, fanden meine Eltern zuerst ebenso absurd. Noch 1994 sagte meine Mutter, sie würde niemals dieses Land betreten, dort sei die Asche noch warm. Meine Großmutter war eine Überlebende. Neun Monate später stellten meine Eltern einen Einreiseantrag bei der deutschen Botschaft. 1995 wurde unser Antrag genehmigt, und wir fingen an, unsere Sachen zu verkaufen: zuerst die Elektrogeräte und das Küchenequipment, dann die Möbel. [...] 1996 waren wir in Deutschland. 1997 dachte ich zum ersten Mal über Selbstmord nach.”

2 Original quote: "Wenn du noch etwas für mich empfindest, dann komm mit."

3 Original quote: "Was passiert, wenn man erst in Ramallah entdeckt, dass man seinen Pass nicht dabeihat. Wird man dann nicht mehr nach Israel reingelassen?' 'Das ist kein Sonntagsausflug', sagte Tal. 'Für mich sieht es hier so ziemlich nach Sonntag aus."' 
she calls her friend Sami and asks him to pick her up (p. 283). But she loses blood and, in the end, she goes into the sunset with her deceased friend Elias. Whether this field in Palestine is her final destination remains to be speculated. But if one understands the end as an indication of her death, then this is a story not only of crossing national boundaries, but also of crossing boundaries between life and death.

\section{CROSSING NATIONAL AND GENDER BOUNDARIES IN THE CONTEXT OF ADOLESCENCE IN SASHA MARIANNA SALZMANN'S AUBER SICH}

Sasha Marianna Salzmann's debut novel, published in 2017, tells the story of Ali (Alissa), who was born in Russia and came to Germany with her family as a Jewish quota refugee in the 1990s. The Jewish roots were primarily a means to an end: "You did everything to leave the beloved Soviet country, you were even ready to become a Jew" (Salzmann, 2017, p. 108, translation by $\mathrm{AJ})^{1}$. The novel consists of two main narrative threads. One is episodically and in an analeptic way - devoted to Ali's family history, especially her great-grandparents, grandparents, and parents. Part of this family history is also the migration of the parents with Ali, her twin brother Anton, and the grandfather to Germany as well as the subsequent life in the asylum home. The second storyline tells of the recent past: Ali is now a young adult who travels to Istanbul to look for her missing brother. Both narrative strands are deeply interwoven. The trip to Istanbul causes the protagonist to begin dealing with her own family history and ultimately even to write a novel based on the memories of the ancestors. So, this journey - even if it does not seem so at first - is also characterised by a movement through space that is paradigmatic for family histories of migrants.

Ali's first border crossing takes her from Russia to Germany by train. The journey takes 36 hours, and during the night they are woken up by customs officials who are expecting a bribe:

Then it was time to get up, pretend you had slept, touch your heart, reach into the bra, where the two hundred dollars were waiting for the officer, an unshaven man with bloodshot eyes who was staring at her in a way that Valja was glad having her husband in the compartment, even if he just crouched fearfully in the corner. (p. 54 , translation by AJ) ${ }^{2}$

1 Original quote: "Man tat alles, um das geliebte Sowjetland zu verlassen, man war sogar bereit, Jude zu werden."

2 Original quote: "Dann hieß es aufstehen, so tun, als hätte man geschlafen, sich ans Herz fassen, in den Büstenhalter, dort wo die zweihundert Dollar auf den Beamten warteten, einen unrasierten Mann mit blutunterlaufenen Augen, der so schaute, dass Valja froh war, ihren Mann mit im Abteil zu haben, auch wenn er nur ängstlich in der Ecke kauerte." 
When arriving in Germany, Ali is overwhelmed by many impressions:

"Everything was jungle, everything was colours, everything scared her and she didn't know whether she was lying on the ground or had fallen into a hole" ( $p$. 55 , translation by $\mathrm{AJ})^{1}$.

She vomits the chicken she ate on the train on the shoes of the uncle who welcomes the family at the train station in Berlin. Years of disillusion are following, during which the family moves from one asylum home to another asylum home. Many years later, the father, whose hopes for a better future in Germany remained unfulfilled, returns to Russia. But the return cannot save him either - "little did he know that there was no such thing as going back" (p. 253, translation by AJ) $)^{2}$. Instead, it leads to suicide. Ali's mother sums up: "Migration kills" (p. 297, translation by AJ) ${ }^{3}$.

The second border crossing leads Ali from Germany to Istanbul. She is looking for her missing brother, but in the course of the journey it becomes clear that she is much more looking for herself, while the existence of her brother becomes more and more questionable. The arrival at Ataturk Airport in Istanbul is reminiscent of the arrival in Berlin. She collapses on the toilet and even though she has not eaten chicken in years, she suddenly has the taste on her tongue and the feeling of vomiting the chicken again (p. 13). Ali is checked very carefully at passport control, because, as the border official explains, "we have a problem in this country with imports from Russia. Women I mean. Imports of women from Russia" (p. 16, translation by AJ) ${ }^{4}$. While Mascha in Grjasnowa's novel is suspected of terrorism by border guards, Ali in Salzmann's novel is mistaken for a Russian prostitute.

For Ali, Turkey becomes a transit zone itself, because during her stay she becomes a man. As with the first time at the train station, the second time at the airport the chicken in the throat announced significant changes. Although the change in appearance of the character made the return even more complicated - "it was already difficult to recognize him on the passport photo on his entry, now it was impossible, even if he shaved, from now on it was a different face" (p. 361, translation by AJ) ${ }^{5}$ this is the first successful backward movement of a border crosser character so far. Nevertheless, this third border crossing - back to Germany - is marked by fears. Ali, who is now

1 Original quote: "Alles war Dschungel, alles war Farben, alles machte ihr Angst und sie wusste nicht, ob sie auf dem Boden lag oder in ein Loch gefallen war."

2 Original quote: "Er wusste nicht, dass es so etwas wie ein Zurückgehen nicht gab."

3 Original quote: "Migration tötet"

4 Original quote: "Wir haben ein Problem in diesem Land mit Importen aus Russland. Frauen, meine ich. Frauenimporten aus Russland."

5 Original quote: "War es bei seiner Einreise schon schwer gewesen, ihn darauf zu erkennen, war es jetzt unmöglich, selbst wenn er sich rasieren würde, ab jetzt war es ein anderes Gesicht." 
calling himself Anton, is afraid of returning home unrecognized like Odysseus:

"Coming back, coming back whereto, into the loving arms of a woman who probably wouldn't recognize him on the platform" (p. 344, translation by AJ)1.

Through the transformation from Ali to Anton at the end of the novel, the twin brother is suspected of never having been real. Außer sich is a novel which connects national border crossing with an overcoming of gender boundaries. With the transgender complex of themes, Salzmann depicts a period of upheaval in adolescence. So, this is a typical border crosser story according to Pabis. But also, the connection to the transgenerational trauma and the contact zones (Hinojosa Picón) can be found when the protagonist's eastward journey is depicted parallel to the westward movements of previous generations.

\section{CROSSING BORDERS AS A MEANS OF LOCATING ONESELF IN DIMITRIJ KAPITELMAN'S DAS LÄCHELN MEINES UNSICHTBAREN VATERS}

Dimitrij Kapitelman's debut novel, published in 2016, tells the story of the Jewish-Russian Kapitelman family who came to Germany as quota refugees from the Ukraine in the 1990s. The novel begins in the present time when the son has grown up. Mainly it is about the search for the Jewish identity of father and son, which leads them to Israel - the country to which they originally wanted to emigrate. There are several flashbacks to his childhood in Kiev and his youth in Leipzig's problematic district of Grünau. The first border crossing takes place in the 1990s and leads the family from Ukraine to a German asylum seekers' home. As in the two previously mentioned novels, this first crossing of boundaries leads to an inner conflict of the characters, who from then on will always have problems with their self-positioning. Therefore, father and son decide to travel to Israel, to look at the parallel universe and to find out whether they should have emigrated to Israel instead of Germany and whether they could have become happier there. The first thing the father has to say about Israel is rather derogatory:

1 Original quote: "Zurückkommen, wohin zurück, in die liebenden Arme einer Frau, die ihn wahrscheinlich nicht erkennen würde am Bahnsteig." 
Sratsch is the first word that my father finds for Israel from his window seat. Freely translated, sratsch means pigsty. The bright blue sea and Tel Aviv's imposing skyline do not elicit a warm syllable from him. But he notices that there is a pile of earth lying around next to one of the runways. (Kapitelman, 2016, p. 65, translation by $\mathrm{AJ})^{1}$

When entering Israel, only the different surnames of father and son arouse suspicion. The son, Dimitrij, explains that in antisemitic Ukraine, his parents arranged that their child should not have a Jewish surname. The border guard reacts extremely understanding: "Semite-solidary, waving smile" (p. 66, translation by AJ) ${ }^{2}$. The border crossing is a trigger for a new level of inner identity negotiations of the protagonist Dimitrij: his inner judgment, "the eternal search for the Jew in me" (p. 257, translation by AJ) ${ }^{3}$. Only when this negotiation has been concluded, he is ready to return to Germany. Part of this trial is also another border crossing, from Israel to Palestine. His Israeli relatives and his father do not condone that trip; they even call him "Arab friend" (p. 91, translation by AJ) ${ }^{4}$. The crossing of the border to Palestine is marked by his fear of being recognized as a person of Jewish descent. He deals with his own prejudices, his "Arab fear" (p. 232, translation by $\mathrm{AJ})^{5}$, and, confronted with the martyr glorification in Nabulus, he imagines: "If we had moved to Israel twenty years ago, one of them might have blown my father and me away while we were sipping pomegranate juice on the bus to Bat Yam" (p. 233, translation by AJ) ${ }^{6}$. He befriends many locals in Palestine and thus gets even more into a loyalty conflict. The return to Israel is uncomplicated for him because of his privileges thanks to the German residence permit. Due to his new friendships, however, he now sees the degrading process that Palestinians must undergo at the border with different eyes. His return is exaggerated by the family:

If Indiana Jones had parachuted down to Borja's birthday table, arrowheads in his back and shoulder pads burning, he would hardly have garnered more attention than me. DIMA SURVIVED! Papa, Mascha, Borja and his wife are excited about my report on the struggle for survival in enemy territory. (p. 254, translation by $\mathrm{AJ})^{7}$

1 Original quote: „Sratsch ist das erste Wort, das Papa von seinem Fensterplatz aus für Israel findet. Frei übersetzt bedeutet sratsch Saustall. Das strahlend blaue Meer und Tel Avivs imposante Skyline entlocken ihm keine warme Silbe. Aber dass neben einer der Landebahnen ein Häufchen Erde herumliegt - das fällt ihm auf."

2 Original quote: "Semitsolidarisches, durchwinkendes Lächeln."

3 Original quote: "die ewige Fahndung nach dem Juden in mir"

4 Original quote: "Araberfreund"

5 Original quote: "Arabangst"

6 Original quote: "Wären wir vor zwanzig Jahren nach Israel gezogen, hätte einer von ihnen vielleicht Papa und mich beim Granatapfelsaftschlürfen im Bus nach Bat Yam weggesprengt."

7 Original quote: "Wäre Indiana Jones per Fallschirm an Borjas Geburtstagstisch heruntergeschossen, mit Pfeilspitzen im Rücken und brennenden Schulterpolstern - er hätte kaum mehr 
At this point it is clear to both of them that living in Israel would have been extremely difficult in the first place. Dimitrij decides to apply for German citizenship: "If anything, I am a German Jew. And not compatible with Israel's society" (p. 270, translation by AJ) ${ }^{1}$. With the trip to Israel, Dimitrij gains a new self-evident way of positioning himself as German. The concept of being a stranger becomes fragile when borders are crossed and leads him to demand for his German identity. Even the father returns to Germany as a less torn character: "Since my father came back from Israel, he has been living on an imported happiness depot. No depressing rastojenstwa far and wide" (p. 280, translation by AJ) ${ }^{2}$. Overall, Kapitelman's novel shows how national, cultural, and religious border crossings may enforce a character's self-placement.

\section{CONCLUSION}

As already announced in the introduction, border crossing turned out to be an important identity-creating moment in the three migratory novels of the third voice that were analysed here. These novels of the third voice which deal with the story of a family in the context of migration as well as the efforts of intercultural characters to locate themselves are not only characterized by one radical and changing border crossing, but rather by multiple border crossings on different levels. All three examined novels not only describe the actual migration movement from the Communist East to Germany in the past and the tension that goes with it (cf. Pabis, 2017, p. 47), but also depict a journey to the Middle East in the presence. As a matter of fact, the border crossing of the presence is closely linked to that of the past.

In Grjasnowa's novel, the protagonist loses what she calls 'home' for the second time. Since the last time her loss has been accompanied by an escape and a border crossing, it seems to be the only way out this time too.

In Kapitelman's novel, the second crossing of boundaries is a necessary result of the first, because the characters hope that this will heal the insecurities and turmoil that the first crossing of boundaries caused. Ever since they had to choose between Israel and Germany, they have always wondered whether they would have been happier had they chosen Israel. The trip to Israel thus represents a glimpse into the parallel universe.

In Salzmann's novel, the two border crossings are even directly linked to one another using the image of the chicken that seems to be stuck

Aufmerksamkeit geerntet als ich. DIMA HAT ÜBERLEBT! Papa, Mascha, Borja und seine Frau fiebern meinem Bericht vom Überlebenskampf im Feindesland entgegen."

1 Original quote: "Wenn überhaupt, bin ich ein deutscher Jude. Und nicht kompatibel mit Israels

Gesellschaft.”

2 Original quote: "Seit Papa aus Israel zurückgekommen ist, zehrt er von einem importierten Fröhlichkeitsdepot. Keine bleierne rastojenstwa weit und breit.” 


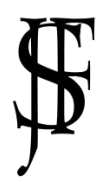

Журнал Фронтирных Исследований. 2021. No 2 | ISSN: 2500-0225

Пограничные исследования в современной европейской литературе | Doi: https://doi.org/10.46539/jfs.v6i2.290

in the protagonist's throat. Like crossing the border itself, the chicken may symbolize a great change that is about to come.

While in all three novels the first border crossing from the home country to Germany is an act of disillusionment and fragmentation for the entire family, the effects of the second border crossing are very diverse. Since the loss of home is linked to the first crossing of the border, the characters hope to find themselves by crossing the border again and to feel at home somewhere. But not all of them succeed. Grjasnowa's protagonist is unable to find a new home until - with the transition from life to death - she is finally reunited with her deceased boyfriend (her lost home). Salzmann's protagonist Alissa, who processed her own masculinity already as a child in the form of an imagined twin brother, needs the spatial distance to her family and home in order to finally face the physical and mental change from woman to man, from Alissa to Anton. The transition allows her/him to be the person she/he wants to be - a different kind of feeling at home. The crossing of the border by Kapitelman's protagonists is most likely to be understood as positive, because in the end the stay helps the son in particular to establish himself as a German Jew.

The possibilities to return are similarly diverse in all three novels. While Grjasnowa's protagonist does not seem to be willing to return from the start, Salzmann's protagonist experiences a form of unrecognized return that has a very old tradition in literary texts. Kapitelman's protagonist cannot return until all his doubts and questions have been resolved. And then he is coming back to Germany even as a happier person who seems to have found himself a little bit more.

The analysis of the three novels supports Pabis' assumption that migration family novels differ from family sagas in the following way: with the experiences of disruption (which arise due to the crossing of national borders), perspective shifts take place. The proposition can be extended with the observation that an attempt to heal the disruption (coping strategy) is made by means of another border crossing. The outcomes of that are quite different. The strong link between border crossings and contact zones with previous generations and the transgenerational memory can predominantly be found in Salzmann's novel. Kapitelman and Grjasnowa tell stories that merely shed some light on the two generations who experienced migration together. However, it becomes clear with all three novels that the act of border crossing stimulates reflection on the own origin and family history. Besides, all three novels can be understood both as family sagas as well as adolescent or coming-of-age literature which deal with topics like puberty, self-discovery, gender transformation, love, loss, study, entry into professional life and so on. The migration background and personal liminal experiences 
have a strong impact on the representation of border crossings, which are always associated with earlier (migratory) border crossings and with boundary crossings in the context of adolescence.

Just as borders and periods of upheaval are recurring motifs in these novels, so are the spaces of transit, like train stations and airports. Another transit space of importance where 'something special happens' is the home for asylum seekers, where the families live after they arrived in Germany. Here, the ideal of a life in Germany, in freedom and independence, clashes with the unadorned and unpleasant reality of the life as an asylum seeker. Also, the journey to the Middle East becomes itself a transit space, in which there is a transition between life and death, woman and man or self-confusion and self-positioning.

Regarding the aspects of the secondary literature, all the three novels that were analysed here are border crosser stories, according to Pabis, which not only depict migration and travel, but also personal liminal experiences. They reflect processes of self-transgression and alienation from the world and the self in connection with the representation of boundary crossings. The foreign, which, according to Waldenfels, appears at the borders in the form of the extraordinary, emerges in the texts only blurredly in the form of a chicken stuck in the throat or a laptop that - from the protagonist's point of view - is blown up unfounded. At the same time, however, due to their migration background and family history, the border crossings are associated with feelings of coming home - for instance when Grjasnowa's protagonist suddenly remembers Baku in Tel Aviv (p. 253) or Kapitelman's protagonist is greeted at the airport like someone finally coming home: "Welcome to Israel, you two! The time had come for you to finally visit your home country" (p. 66, translation by AJ) ${ }^{1}$.

\section{ACKNOWLEDGEMENTS}

This output has been co-financed under Project U21 - Improving the Quality of the Grant Competition and Teaching in Doctoral Study Programmes at UJEP CZ.02.2.69/0.0/0.0/19_073/0 016947.

\section{References}

Assmann, A. (2007). Geschichte im Gedächtnis. Von der individuellen Erfahrung zur öffentlichen Inszenierung [History in memory. From individual experience to public staging]. München: C. H. Beck. (In German).

1 Original quote: "Willkommen in Israel, ihr zwei! Wurde ja auch Zeit, dass ihr mal eure Heimat besucht." 
Aumüller, J. (2010). Wie viele Generationen dauert Integration? Wie Begriffe unser Bild von Gesellschaft prägen [How many generations does integration take? How terms shape our image of society]. Retrieved from Migrationspolitisches Portal der Heinrich Böll Stiftung website: https:/heimatkunde.boell.de/de/2013/11/18/wie-viele-generationen-dauert-integration-wie-begriffe-unser-bild-von-gesellschaft-pr\%C3\%A4gen (In German)

Bhabha, H. K. (1994). The location of culture. New York: Routledge.

Chiellino, C. (2001). Liebe und Interkulturalität. Essays 1988-2000 [Love and Interculturality. Essays 1988-2000]. Tübingen: Stauffenburg. (In German).

Cornejo, R., Piontek, S., Sellmer, I., \& Vlasta, S. (Eds.). (2014). Deutschsprachige Gegenwartsliteratur aus Mittel- und Osteuropa [German-language contemporary literature from Central and Eastern Europe]. Wien: Praesens Verlag. (In German).

Drosihn, Y., Jandl, I., \& Kowollik, E. (2020). Trauma - Generationen - Erzählen. Transgenerationale Narrative in der Gegenwartsliteratur [Trauma - Generations - Narrative. Transgenerational Narratives in Contemporary Literature]. Berlin: Frank \& Timme. (In German).

Grjasnowa, O. (2012). Der Russe ist einer, der Birken liebt [The Russian is one who loves birches] (6th ed.). München: dtv. (In German).

Hardtke, T., Kleine, J., \& Payne, C. (Eds.). (2017). Niemandsbuchten und Schutzbefohlene [Noman's pens and protectors]. Göttingen: V\&R Unipress. (In German).

Hausbacher, E. (2009). Poetik der Migration. Transnationale Schreibweisen in der zeitgenössischen russischen Literatur [Poetics of Migration. Transnational modes of writing in contemporary Russian literature]. Tübingen: Stauffenburg. (In German).

Hinojosa Picón, O. (2019). Barbara Honigmann: Das Leben an der Grenze erinnern und erzählen [Barbara Honigmann: Remembering and recounting life on the border]. In M. B. Hölscher \& C. Jurcic (Eds.), Narrationen in Bewegung. Deutschsprachige Literatur und Migration [Narratives on the Move. German-language literature and migration] (pp. 165-172). Bielefeld: Aisthesis Verlag. (In German).

Jänchen, A. (2019). Die dritte Stimme. Migration in der jüngeren deutschsprachigen Literatur [The Third Voice. Migration in recent German-language literature]. Baden-Baden: Tectum Verlag. (In German).

Kapitelman, D. (2016). Das Lächeln meines unsichtbaren Vaters [The smile of my invisible father]. München: Hanser Berlin. (In German).

Olga Grjasnowa findet Label 'Migrationsliteratur' unsäglich [Interview mit Olga Grjasnowa] [Olga Grjasnowa finds the label 'migration literature' unspeakable [Interview with Olga Grjasnowa]]. (2017, March 25). Retrieved from Welt website: https:// www.welt.de/newsticker/dpa_nt/infoline_nt/boulevard_nt/article163 153046/OlgaGrjasnowa-findet-Label-Migrationsliteratur-unsaeglich.html

Oppenrieder, W., \& Thurmair, M. (2003). Sprachidentität im Kontext von Mehrsprachigkeit [Language identity in the context of multilingualism]. In N. Janich \& C. ThimMabrey (Eds.), Sprachidentität - Identität durch Sprache [Language identity - identity through language] (pp. 39-60). Tübingen: Gunter Narr Verlag. (In German). 
Pabis, E. (2017). Literarische Grenzgänge. Dimensionen der Fremdheit in der deutschsprachigen Gegenwartsliteratur der Schweiz [Literary Border Crossings. Dimensions of foreignness in contemporary German-language literature in Switzerland]. Wien: Praesens Verlag. (In German).

Pekar, T. (2017). Heimat, Anpassung und Transit in der Literatur des Exils und der Migration [Home, Adaptation and Transit in the Literature of Exile and Migration]. In S. Egger, W. Bonner, \& E. W. B. Hess-Lüttich (Eds.), Transiträume und transitorische Begegnungen in Literatur, Theater und Film [Transit Spaces and Transitory Encounters in Literature, Theatre and Film] (pp. 131-144). Frankfurt am Main: Peter Lang Verlag. (In German).

Pratt, M. L. (1991). Arts of the Contact Zone. Profession, (91), 33-40.

Rauwald, M. (2013). Vererbte Wunden: Transgenerationale Weitergabe traumatischer Erfahrungen [Inherited wounds: Transgenerational transmission of traumatic experiences]. Weinheim/Basel: Beltz Verlag. (In German).

Salzmann, S. M. (2017). Außer sich [Out of himself]. Berlin: Suhrkamp. (In German).

Schimanski, J., \& Wolfe, S. F. (Eds.). (2017). Border Aesthetics. Concepts an Intersections. Oxford/New York: Berghahn.

Stanišić, S. (2008, November). Three Myths of Immigrant Writing: A View from Germany. Retrieved from WORDS without BORDERS website: https://www.wordswithoutborders.org/article/three-myths-of-immigrant-writing-a-view-from-germany

Steidl, S. (2017). Der Flüchtling als Grenzgestalter? Zur Dialektik des Grenzverletzers in Abbas Khiders Debütroman Der falsche Inder [The Refugee as Border Shaper? On the Dialectic of the Border Violator in Abbas Khider's Debut Novel The Wrong Indian]. In T. Hardtke, J. Kleine, \& C. Payne (Eds.), Niemandsbuchten und Schutzbefohlene [No-man's pens and protectors] (pp. 305-320). Göttingen: V\&R Unipress. (In German).

Waldenfels, B. (1990). Der Stachel des Fremden [The Sting of the Stranger]. Frankfurt am Main: Suhrkamp. (In German).

Waldenfels, B. (2006). Grundmotive einer Phänomenologie des Fremden [Basic Motifs of a Phenomenology of the Stranger]. Frankfurt am Main: Suhrkamp. (In German).

Wilhelmer, L. (2015). Transit-Orte in der Literatur. Eisenbahn - Hotel - Hafen - Flughafen [Transit places in literature. Railway - Hotel - Port - Airport]. Transcript. (In German).

\section{Список литературы}

Assmann, A. (2007). Geschichte im Gedächtnis. Von der individuellen Erfahrung zur öffentlichen Inszenierung [History in memory. From individual experience to public staging]. München: C. H. Beck. (In German).

Aumüller, J. (2010). Wie viele Generationen dauert Integration? Wie Begriffe unser Bild von Gesellschaft prägen [How many generations does integration take? How terms shape our image of society]. Retrieved from Migrationspolitisches Portal der Heinrich Böll Stiftung website: https://heimatkunde.boell.de/de/2013/11/18/wie-viele-gen- 
erationen-dauert-integration-wie-begriffe-unser-bild-von-gesellschaft-pr\%C3\%A4gen (In German)

Bhabha, H. K. (1994). The location of culture. New York: Routledge.

Chiellino, C. (2001). Liebe und Interkulturalität. Essays 1988-2000 [Love and Interculturality. Essays 1988-2000]. Tübingen: Stauffenburg. (In German).

Cornejo, R., Piontek, S., Sellmer, I., \& Vlasta, S. (Eds.). (2014). Deutschsprachige Gegenwartsliteratur aus Mittel- und Osteuropa [German-language contemporary literature from Central and Eastern Europe]. Wien: Praesens Verlag. (In German).

Drosihn, Y., Jandl, I., \& Kowollik, E. (2020). Trauma - Generationen - Erzählen. Transgenerationale Narrative in der Gegenwartsliteratur [Trauma - Generations - Narrative. Transgenerational Narratives in Contemporary Literature]. Berlin: Frank \& Timme. (In German).

Grjasnowa, O. (2012). Der Russe ist einer, der Birken liebt [The Russian is one who loves birches] (6th ed.). München: dtv. (In German).

Hardtke, T., Kleine, J., \& Payne, C. (Eds.). (2017). Niemandsbuchten und Schutzbefohlene [Noman's pens and protectors]. Göttingen: V\&R Unipress. (In German).

Hausbacher, E. (2009). Poetik der Migration. Transnationale Schreibweisen in der zeitgenössischen russischen Literatur [Poetics of Migration. Transnational modes of writing in contemporary Russian literature]. Tübingen: Stauffenburg. (In German).

Hinojosa Picón, O. (2019). Barbara Honigmann: Das Leben an der Grenze erinnern und erzählen [Barbara Honigmann: Remembering and recounting life on the border]. In M. B. Hölscher \& C. Jurcic (Eds.), Narrationen in Bewegung. Deutschsprachige Literatur und Migration [Narratives on the Move. German-language literature and migration] (pp. 165-172). Bielefeld: Aisthesis Verlag. (In German).

Jänchen, A. (2019). Die dritte Stimme. Migration in der jüngeren deutschsprachigen Literatur [The Third Voice. Migration in recent German-language literature]. Baden-Baden: Tectum Verlag. (In German).

Kapitelman, D. (2016). Das Lächeln meines unsichtbaren Vaters [The smile of my invisible father]. München: Hanser Berlin. (In German).

Olga Grjasnowa findet Label 'Migrationsliteratur' unsäglich [Interview mit Olga Grjasnowa] [Olga Grjasnowa finds the label 'migration literature' unspeakable [Interview with Olga Grjasnowa]]. (2017, March 25). Retrieved from Welt website: https:// www.welt.de/newsticker/dpa_nt/infoline_nt/boulevard_nt/article163 153 046/OlgaGrjasnowa-findet-Label-Migrationsliteratur-unsaeglich.html

Oppenrieder, W., \& Thurmair, M. (2003). Sprachidentität im Kontext von Mehrsprachigkeit [Language identity in the context of multilingualism]. In N. Janich \& C. ThimMabrey (Eds.), Sprachidentität - Identität durch Sprache [Language identity - identity through language] (pp. 39-60). Tübingen: Gunter Narr Verlag. (In German).

Pabis, E. (2017). Literarische Grenzgänge. Dimensionen der Fremdheit in der deutschsprachigen Gegenwartsliteratur der Schweiz [Literary Border Crossings. Dimensions of foreignness in contemporary German-language literature in Switzerland]. Wien: Praesens Verlag. (In German). 
Pekar, T. (2017). Heimat, Anpassung und Transit in der Literatur des Exils und der Migration [Home, Adaptation and Transit in the Literature of Exile and Migration]. In S. Egger, W. Bonner, \& E. W. B. Hess-Lüttich (Eds.), Transiträume und transitorische Begegnungen in Literatur, Theater und Film [Transit Spaces and Transitory Encounters in Literature, Theatre and Film] (pp. 131-144). Frankfurt am Main: Peter Lang Verlag. (In German).

Pratt, M. L. (1991). Arts of the Contact Zone. Profession, (91), 33-40.

Rauwald, M. (2013). Vererbte Wunden: Transgenerationale Weitergabe traumatischer Erfahrungen [Inherited wounds: Transgenerational transmission of traumatic experiences]. Weinheim/Basel: Beltz Verlag. (In German).

Salzmann, S. M. (2017). Außer sich [Out of himself]. Berlin: Suhrkamp. (In German).

Schimanski, J., \& Wolfe, S. F. (Eds.). (2017). Border Aesthetics. Concepts an Intersections. Oxford/New York: Berghahn.

Stanišić, S. (2008, November). Three Myths of Immigrant Writing: A View from Germany. Retrieved from WORDS without BORDERS website: https://www.wordswithoutborders.org/article/three-myths-of-immigrant-writing-a-view-from-germany

Steidl, S. (2017). Der Flüchtling als Grenzgestalter? Zur Dialektik des Grenzverletzers in Abbas Khiders Debütroman Der falsche Inder [The Refugee as Border Shaper? On the Dialectic of the Border Violator in Abbas Khider's Debut Novel The Wrong Indian]. In T. Hardtke, J. Kleine, \& C. Payne (Eds.), Niemandsbuchten und Schutzbefohlene [No-man's pens and protectors] (pp. 305-320). Göttingen: V\&R Unipress. (In German).

Waldenfels, B. (1990). Der Stachel des Fremden [The Sting of the Stranger]. Frankfurt am Main: Suhrkamp. (In German).

Waldenfels, B. (2006). Grundmotive einer Phänomenologie des Fremden [Basic Motifs of a Phenomenology of the Stranger]. Frankfurt am Main: Suhrkamp. (In German).

Wilhelmer, L. (2015). Transit-Orte in der Literatur. Eisenbahn - Hotel - Hafen - Flughafen [Transit places in literature. Railway - Hotel - Port - Airport]. Transcript. (In German). 